\title{
Diagnosis of acute diarrhea in pigs and piglets in Meghalaya, India
}

\author{
Das, A., ${ }^{1 \star}$ Mazumder, Y., ${ }^{2}$ Dutta, B. K., ${ }^{3}$ Kumar, A. ${ }^{4}$ and Selvi S. ${ }^{1}$ \\ ${ }^{1}$ Department of Biotechnology, Bannari Amman Institute of Technology, Sathyamangalam, Tamil Nadu, India. \\ ${ }^{2}$ Department of Biotechnology Engineering, Nagarjuna College of Engineering and Technology, Bangalore, Karnataka, \\ India. ${ }^{3}$ Department of Ecology and Environmental Science, Assam University, Silchar, Assam, India. ${ }^{4}$ Division of Animal \\ Health, Indian Council of Agricultural Research for NEH Region, Umiam, Meghalaya.
}

E-mail: drarunavadas@rediffmail.com

Received 25 January 2009; received in revised form 20 February 2009; accepted 20 February 2009

\begin{abstract}
This paper reports the diagnosis of acute diarrhoea in three male pigs and two female piglets died in an organized pig farm in Meghalaya, India. Intestinal contents and liver samples from dead pigs and piglets were investigated for isolation and identification of bacteria. Bacterial isolation confirmed the causative agent as Clostrodium perfringens. A total of eight $C$. perfringens were isolated out of 10 clinical samples. Isolates harbored identical double plasmid DNA of molecular weights $42.8 \mathrm{~kb}$ and $51.9 \mathrm{~kb}$ common to all. In polymerase chain reaction (PCR), all the eight (100\%) clinical isolates harboured alpha toxin gene (cpa) and beta2 toxin gene (cpb2). None of the isolates were positive for beta, epsilon, iota and enterotoxin genes. The PCR analysis revealed that all isolates derived from acute diarrhoea belonged to $C$. perfringens type A. The partial cpa gene sequences from two Indian field isolates in BLAST showed similarity values greater than $99 \%$ to the published database sequences of $C$. perfringens. The phylogenetic analysis also revealed 98.6 to $100 \%$ sequence homology among the isolates studied. The findings suggested that $C$. perfringens type A having additional cpb2 gene might play a significant role in occurrence of acute diarrhoea in pigs and piglets in Meghalaya, India.
\end{abstract}

Keywords: Clostridium perfringens, acute diarrhoea, pig, piglet, plasmids, polymerase chain reaction

\section{INTRODUCTION}

Pig population in the North Eastern (NE) region of India is reared only for the meat production. The demand of pork meat in Meghalaya state is higher than any other states in NE India. However, every year, the single most important problem that plagues the pig production sector of Meghalaya is the occurrence of various diseases, contributing significantly to the loss of pig population. Amongst various diseases that cause a threat to the pig population, the occurrence of gastrointestinal tract infections with mild or acute diarrhoea caused by the bacteria is major cause of concern. Acute diarrhoea is the most obvious outward sign of a gut abnormality and should always be treated as potentially serious. Amongst various bacteria, Clostridium perfringens strains are frequently isolated from the gastroenteritis cases in pigs and piglets (Songer, 1996).

C. perfringens is an anaerobic, Gram positive, spore forming bacteria, present in soil, sewer water and in gastro intestinal tracts of man and animals. It is classified into five types $A$ to $E$ on the basis of production of four major lethal toxins- alpha (CPA), beta (CPB), epsilon (ETX) and iota (IA) (Songer and Meer, 1996). C. perfringens types $A$ and $C$ are the principal pathogenic agents of enteric diseases in pig and piglet. The type $A$ ${ }^{*}$ Corresponding author produces mainly the alpha toxin and is a part of the normal intestinal microflora, but causes gastroenteritis in pigs and piglets, manifested by acute diarrhoea under critical conditions that have not been identified completely (Songer, 1996). The type C, producer of alpha and beta toxins is found in very small numbers in the intestinal tract of healthy animals, is the agent causing necrotic enteritis in piglets. Along with alpha and beta toxins, other toxins like beta2 (CPB2) toxin and enterotoxin (CPE) produced by all the types also associated with the gastroenteritis of pig and piglet (Songer and Meer, 1996; Gibert et al., 1997).

Plasmid profiling nowadays has been used by many researchers for differentiation and characterization of the C. perfringens isolates (Eisgruber et al., 1996). Use of molecular techniques like PCR facilitates easy typing of $C$. perfringens by detecting toxin genes in clinical samples (Songer and Meer, 1996). Further, sequencing and phylogenetic analysis of the virulence genes from the clinical isolates helps in both genus and species specific identification and genetic diversity analysis of the organism (Rooney et al., 2006). Present study reports the occurrence of acute diarrhoea in pig and piglet caused by the $C$. perfringens type $A$ isolates. 


\section{MATERIALS AND METHODS}

\section{History of animals and sample collection}

A total of 149 pigs and 96 piglets (New Yorkshire crossed with indigenous khasi breed) were kept in semi-intensive system of rearing in an organized pig farm in Meghalaya, India. Three male pigs of age 12 to 14 months old and two female piglets of two to three months were suddenly developed off feed, poor growth, anorexia, pyrexia, rough hair coat and prolonged episodes of diarrhoea. The atmospheric temperature and humidity was recorded between 25 to $35{ }^{\circ} \mathrm{C}$ and 80 to $90 \%$ respectively with heavy rainfall during the period of April, 2006. The animals were isolated and unresponsive to the treatment with 5 $\mathrm{mg}$ tetracycline (Himedia, Mumbai) per $\mathrm{kg}$ of body weight parentarily for three days. On fourth day, the animals were died. The postmortem was performed within two to four hours of death. Body surfaces were examined for any injuries or wound. All the internal organs were thoroughly examined and any macroscopic and gross lesions observed were recorded. The small and large intestinal contents collected from each died pigs and piglets during the postmortem examination and from healthy pig and piglet (control) during slaughtering were scientifically processed for microbiological investigation.

\section{Bacterial isolation and biochemical characterization}

Samples from small and large intestinal contents were attempted for both aerobic and anaerobic bacterial isolations. For aerobic isolation, each sample contents were aseptically inoculated in brain heart infusion broth (Oxoid) and tetrathionate broth (Oxoid). The brain heart infusion broth was incubated at $37^{\circ} \mathrm{C}$, while tetrathionate broth was incubated at $42{ }^{\circ} \mathrm{C}$ for $24 \mathrm{~h}$. Inoculum from each tube were streaked to freshly prepared sterile nutrient agar (Himedia, Mumbai), MacConkey lactose agar (Himedia, Mumbai), brilliant green agar (Himedia, Mumbai) and $10 \%$ sheep blood agar (Oxoid, UK) incubated at $37^{\circ} \mathrm{C}$ for $24 \mathrm{~h}$.

For anaerobic isolation, each sample contents were aseptically inoculated in Robertson's cooked meat (RCM) broth medium supplemented with glucose, hemin and vitamin $\mathrm{K}$ (Himedia, Mumbai), overlaid with neutral oil and incubated at $37^{\circ} \mathrm{C}$ for $24 \mathrm{~h}$. The inoculums from the RCM media were seeded onto $10 \%$ goat blood agar and incubated anaerobically with an anaerobic gas-pack system (BBL Microbiology Systems Cockeysville, Md. [Div. Becton Dickinson and Co.]) for $24 \mathrm{~h}$ at $37^{\circ} \mathrm{C}$. Bacterial colonies were purified based on the size, shape, color and patterns of haemolysis on goat blood agar and were subjected to Gram's and malachite spore staining. The isolates were identified based on the gelatinase test, litmus milk test, deoxyribonuclease (DNase) test, lecithinase test on egg yolk agar media (Himedia, Mumbai) and sugar fermentation test (glucose, maltose, mannitol, inositol and lactose). Bacterial colonies were finally identified as per standard bacteriological procedures (Holt et al., 1994).

\section{Detection of plasmid}

One milliliter of bacterial culture grown overnight anaerobically in brain heart infusion broth at $37^{\circ} \mathrm{C}$ was used for the extraction of plasmid DNA by alkali lysis method (Birnboim and Doly, 1979). The plasmid DNA was finally dissolved in $35 \mu \mathrm{L}$ of TE-Rnase $(1 \mathrm{mg} / \mathrm{mL}$ in $10 \mathrm{mM}$ tris-hydrochloric acid and $1 \mathrm{mM}$ ethylenediamine tetraacetic acid; $\mathrm{pH}$ 8.0) solution, electrophoresed in $0.7 \%$ agarose dissolved in $1 \times$ TAE (tris-acetate-EDTA; pH 8.0) buffer and stained with $0.4 \mu \mathrm{g} / \mathrm{mL}$ ethidium bromide. The molecular weight of the plasmids was determined by comparing with known DNA ladder ( $\lambda$ DNA / Hind III digest; GENEI, Bangalore). The separated plasmid DNA bands were visualized and photographed in gel doc system (Image Master® VDS, Pharmacia Biotech, Sweden).

\section{Detection of toxin genes by polymerase chain reaction}

The isolates of $C$. perfringens were tested to detect the alpha toxin gene (cpa), beta toxin gene $(c p b)$, epsilon toxin gene (etx), iota toxin gene (iA), enterotoxin gene (cpe) and beta2 toxin gene (cpb2) by PCR assay (Songer and Meer, 1996).

Freshly grown bacterial colonies from solid media plates were suspended in $200 \mu \mathrm{L}$ of Milli-Q water in a microcentrifuge tube, gently vortexed and boiled for 10 min in a water bath. Supernatant after centrifugation at $10000 \mathrm{~g}$ for $5 \mathrm{~min}$ was used as a template DNA. The amplification was carried out in $25 \mu \mathrm{L}$ reaction volume containing $12.5 \mu \mathrm{L}$ of $2 \times$ PCR master mix (Promega, USA) containing $4 \mathrm{mM}$ magnesium chloride, $0.4 \mathrm{mM}$ of deoxynucleotide triphosphates (dNTPs), $0.5 \mathrm{U}$ of Taq DNA polymerase, $150 \mathrm{mM}$ tris-hydrochlroric acid, $\mathrm{pH} 8.5$ (Promega, USA), $0.5 \mu \mathrm{M}$ primers and $2.5 \mu \mathrm{L}$ of template DNA. The PCR reactions were performed in iCycler (BioRad, USA). After initial denaturation at $94{ }^{\circ} \mathrm{C}$ for 4 min, the amplification cycle had denaturation, annealing and extension at $94^{\circ} \mathrm{C}, 55^{\circ} \mathrm{C}$ and $72{ }^{\circ} \mathrm{C}$ for 1 min each respectively. Final extension was done at $72^{\circ} \mathrm{C}$ for $10 \mathrm{~min}$. The specific forward and reverse primer pairs for cpa gene of 324 bp were 5'-gctaatgttactgccgttga-3' and 5'cctctgatacatcgtgtaag-3' (Titbal et al., 1989), cpb gene of 180 bp were 5'-gcgaatatgctgaatcatcta-3' and 5'gcaggaacattagtatatcttc-3' (Hunter et al., 1993), etx gene of 655 bp were 5'-gcggtgatatccatctattc-3' and 5'ccacttacttgtcctactaac-3' (Hunter et al., 1992), iA gene of 446 bp were 5'-actactctcagacaagacag-3' and 5'ctttccttctattactatacg-3' (Perelle et al., 1993), cpb2 gene of 567 bp were 5'-agatttaaatatgatcctaacc-3' and 5'caatacccttcaccaaatactc-3' (Gibert et al., 1997) and cpe gene of 233 bp were 5'-ggagatggttggatattagg-3' and 5'ggaccagcagttgtagata-3' (Czeczulin et al., 1996) were commercially synthesized (GENSET, USA). $C$. perfringens type $A$ positive for $c p a$ and $c p b 2$ genes isolated from atypical blackleg in cattle was used as positive control (Shome et al., 2006) and C. septicum strain negative for cpa and $c p b 2$ genes was used as negative control. The PCR amplicons $(5 \mu \mathrm{L})$ were 
electrophoresed in $1.5 \%$ agarose gel in TAE buffer, stained with ethidium bromide and observed in gel doc system.

\section{Sequencing of PCR amplified product}

Two isolates- CP45 and CP4 derived from small intestinal contents of pig and piglets respectively died were subjected for sequencing. The PCR amplified products of partial cpa gene of $C$. perfringens were purified using QIA quick $^{\circledR}$ PCR purification kit (QIAGEN, USA) and sequenced in an automated DNA sequencer (Microsynth, Switzerland and Genei, Bangalore, India). Partial sequences obtained were submitted to BLAST analysis (Altschul et al., 1990) to determine the similarities to other sequences available in GenBank. The cpa gene sequences derived from pig and piglet were deposited into the GenBank under the accession numbers DQ838704 and DQ838705 respectively. The partial sequences of 292 nucleotide bases were aligned with the corresponding sequences of three selected $C$. perfringens isolated from bovine enterotoxaemia from USA (DQ184079), healthy chicken from Denmark (AF477009) and soil from Japan (NC_003366) available in the GenBank by using ClustalW algorithm of MegAlign program (DNASTAR, Lasergene, USA). The phylogenetic analysis of the nucleotide sequences and 97 deduced amino acids residues were also analysed by using same programme.

\section{RESULTS AND DISCUSSION}

On postmortem, the small intestines from pigs and piglets were observed to be diffusely congested and edematous. However, three out of five cases severe lesions and mild necrosis were observed in both small and large intestines. Rest other organs were apparently healthy. The symptoms and postmortem findings were suggestive of acute diarrhoea in pigs and piglets also reported earlier (Songer, 1996; Waters et al., 2003). Samples on aerobic isolation yielded a few mixed colonies of staphylococcus and pseudomonas bacteria. No other unidentified bacterial colonies were observed during aerobic isolation. On anaerobic isolation process, only pure bacterial colonies showing alpha and beta haemolysis on goat blood agar was observed. Isolates were non-motile, Gram positive, rods shaped with sub-terminal oval endospores. All isolates showed gelatinase, DNase and lecithinase enzyme activities and produced stormy fermentation, acidity, reduction, coagulation of litmus milk and fermented glucose, lactose and galactose sugars. Upon detailed bacteriological investigation, nine isolates were identified as Clostridium perfringens. Of these nine isolates, eight isolates were originated from the acute diarrhoea cases (five from pigs and three from piglets) and one isolate from healthy piglet (control) (Table 1).

However, no $C$. perfringens were isolated from healthy pig (control). This revealed the etiological agent $C$. perfringens in association with acute diarrhoea in pig and piglet. The occurrence of $C$. perfringens in association with diarrhoea in pig and piglet has been reported earlier
(Gibert et al., 1997; Klaasen et al., 1999; Garmory et al., 2000). The role of $C$. perfringens in present study was made clear by isolation of the organism alone under anaerobic conditions, without any other bacteria. Further, aerobic isolation had not yielded any dominant bacterial type suggestive of enteric infection.

In this study, isolates of $C$. perfringens harboured identical double plasmids of molecular weight $42.8 \mathrm{~kb}$ and $51.9 \mathrm{~kb}$ (Table 1). The $42.8 \mathrm{~kb}$ plasmid from VPI 11268 strains of $C$. perfringens was detected earlier (Squires et al., 1984) and the identical plasmid pattern was reported to be very common in clinical isolates (Eisgruber et al., 1996).

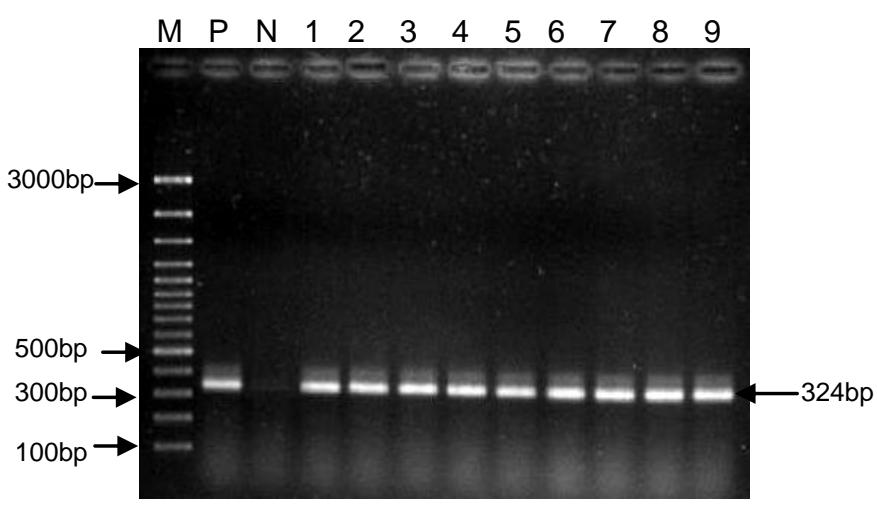

Figure 1: Detection of 324bp fragment of alpha toxin genes of $C$. perfringens by PCR. Lane $\mathrm{P}$ : positive control; lane $\mathrm{N}$ : negative control; lanes 1 to 9 : field isolates positive for alpha toxin genes; lane M: 100bp marker DNA.

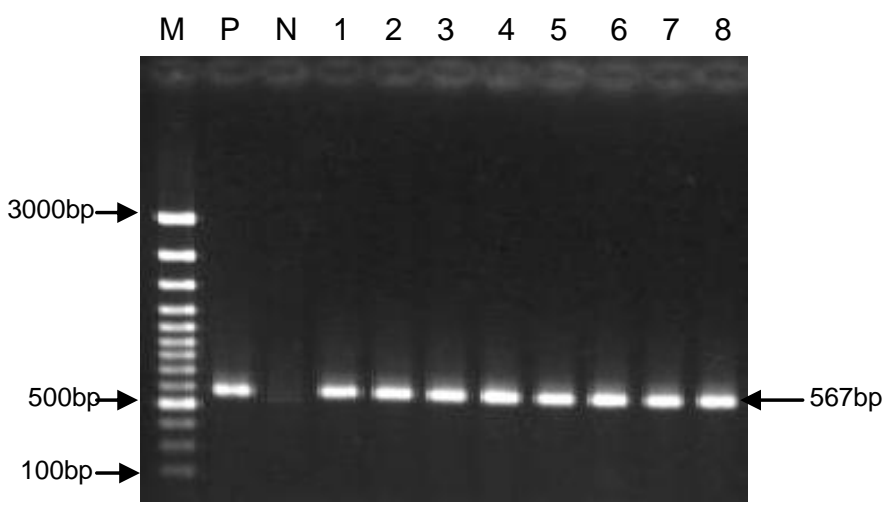

Figure 2: Detection of 567bp fragment of beta2 toxin genes of $C$. perfringens by PCR. Lane P: positive control; lane $\mathrm{N}$ : negative control; lanes 1 to 8: field isolates positive for beta2 toxin genes; lane M: $100 \mathrm{bp}$ marker DNA. 
Mal. J. Microbiol. Vol 5(1) 2009, pp. 38-44

Table 1: Sample details, plasmid profiles and toxin genes of nine Clostridium perfringens

\begin{tabular}{|c|c|c|c|c|c|c|c|c|c|c|}
\hline \multirow[t]{2}{*}{ Sample number } & \multirow[t]{2}{*}{ Sample nature } & \multirow[t]{2}{*}{ Isolate number } & \multirow{2}{*}{$\begin{array}{l}\text { Source with age } \\
\text { (months) }\end{array}$} & \multirow[t]{2}{*}{ Plasmid (kb) } & \multicolumn{6}{|c|}{ Toxin gene detected by PCR } \\
\hline & & & & & cpa & $c p b$ & etx & iA & $c p b 2$ & cpe \\
\hline P-AE1 & Small intestinal contents & CP45 & Pig (12) & $42.8,51.9$ & + & - & - & - & + & - \\
\hline P-AE2 & Large intestinal contents & CP46 & & $42.8,51.9$ & + & - & - & - & + & - \\
\hline P-AE3 & Small intestinal contents & CP47 & Piglet (2) & $42.8,51.9$ & + & - & - & - & + & - \\
\hline P-AE4 & Large intestinal contents & CP48 & & $42.8,51.9$ & + & - & - & - & + & - \\
\hline P-AE5 & Small intestinal contents & CP49 & Pig (13) & $42.8,51.9$ & + & - & - & - & + & - \\
\hline P-AE6 & Large intestinal contents & CPA50 & & $42.8,51.9$ & + & - & - & - & + & - \\
\hline P-AE7 & Small intestinal contents & CPA51 & Piglet (3) & $42.8,51.9$ & + & - & - & - & + & - \\
\hline P-AE9 & Small intestinal contents & CPA52 & Pig (14) & $42.8,51.9$ & + & - & - & - & + & - \\
\hline P-CONTROL & Small intestinal contents & CPXX & Piglet (4) & $42.8,51.9$ & + & - & - & - & - & - \\
\hline
\end{tabular}

$\mathrm{kb}=$ kilo bases; + = detected; - = not detected 

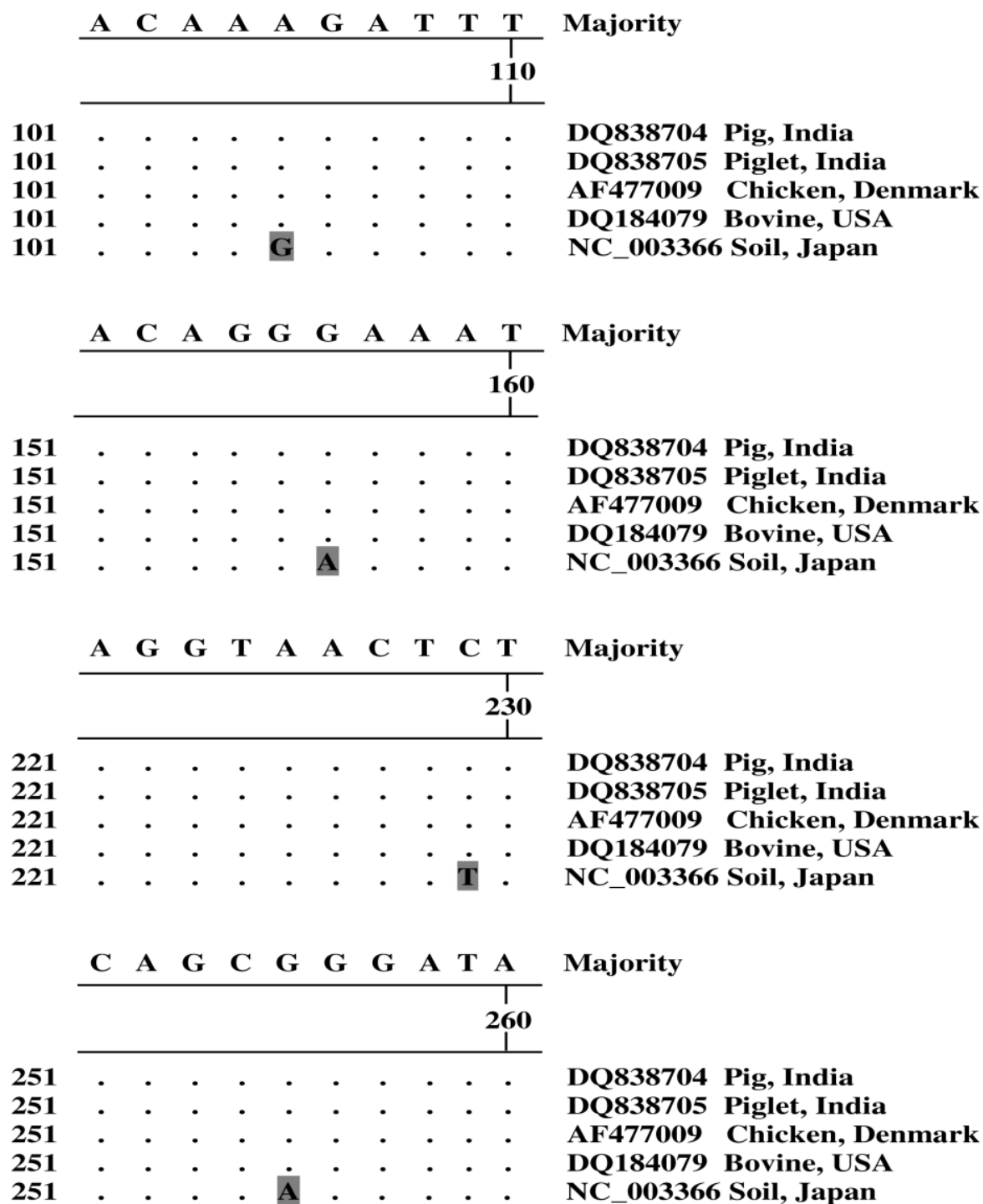

Figure 3: Nucleotide sequence polymorphic sites of 292 bp fragment of cpa gene of $C$. perfringens. The 'dots' and 'shade' represent the residues that match the consensus exactly and that differ from the consensus respectively

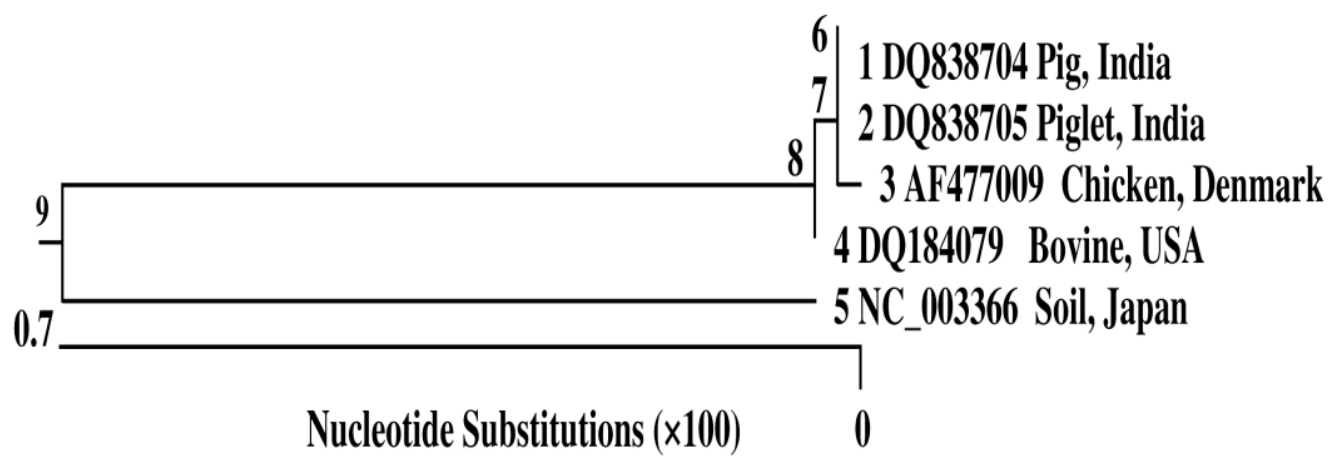

Figure 4: Phylogenetic tree analysis based on the nucleotide sequence of partial alpha toxin gene of $C$. perfringens 
In PCR analysis, out of six virulence genes of $C$. perfringens screened only alpha toxin gene (cpa) of 324bp fragment (Table 1 and Figure 1) and beta2 toxin gene (cpb2) of $567 \mathrm{bp}$ fragment were detected from all the eight $C$. perfringens isolates originated from acute diarrhoeic cases (Table 1 and Figure 2). However, one isolate originated from healthy piglet (control) was found positive for only alpha toxin gene (cpa). None of the isolates were found positive for $c p b$, iA, etx and $c p e$ toxin genes. The PCR assay thus revealed that all the field isolates were $C$. perfringens type $A$. Similar detection of cpa and cpb2 genes from the isolate of $C$. perfringens type $A$ associated with acute diarrhoea in pigs and piglets by PCR has been reported (Klaasen et al., 1999; Germory et al., 2000; Bueschel et al., 2003). In the present study, $c p b 2$ gene is not detected from the $C$. perfringens type $\mathrm{A}$ derived from healthy piglet (control). However, $100 \%$ prevalence of C. perfringens type A isolates with additional cpb2 genes in pigs and piglets suffering from acute diarrhoea in this study is much higher than the previous reporting $82 \%$ for piglets suffering from diarrhea (Germory et al., 2000) and $91.8 \%$ prevalence in neonatal piglets suffering from diarrhea or enteritis (Bueschel et al., 2003). This suggested that the beta2 toxin gene (cpb2) of $C$. perfringens type $A$ is significantly associated with the acute diarrhoea. None of the isolates in this study were positive for any of the $c p b$, etx, $i \mathrm{~A}$ and even cpe toxin genes. In correlation with our result, the CPE negative $C$. perfringens type $A$ isolates associated with piglets diarrhea was also reported (Kanakaraj et al., 1998; Czanderlova et al., 2006). This is possible because, less than $5 \%$ of the global $C$. perfringens type $A$ isolates are cpe positive (Czeczulin et al., 1993). As classical identification methods are expensive, time consuming and also gives low sensitivity results, PCR can be very useful tool to determine the presence of toxin genes and for typing of $C$. perfringens from the clinical samples.

The partial cpa gene sequences of pig and piglets in BLAST showed similarity values greater than $99 \%$ to the published database sequences of $C$. perfringens. The comparative alignment study of partial cpa gene sequences and corresponding 97 deduced amino acid residues of two Indian field isolates and two reference sequences derived from bovine enterotoxaemia (USA) and healthy chicken (Denmark) showed no nucleotide substitution and no change in proteins respectively in compare to majority (Figure 3 ). Hence, all are placed in a single cluster in phylogenetic tree (Figure 4). The reference sequence originated from soil (Japan) had four nucleotide substitutions at positions 105 (Adenine to Guanine), 156 (Guanine to Adenine), 229 (Cytosine to Thymine) and 255 (Guanine to Adenine) with out any change of proteins, placed independently in the phylogram. All these nucleotide substitutions occurred in third nucleotide base of codons which is predominantly silent (Rooney et al., 2006). The phylogenetic analysis also revealed 98.6 to $100 \%$ sequence homology among the isolates suggesting that the partial cpa gene of $C$. perfringens used in this study is highly conserved among isolates irrespective of different source of isolation and geographical distribution. Similarly, a study conducted by researchers also suggested that the cpa sequences of $C$. perfringens are highly conserved and bourn a close homology between the isolates derived from human and animals (Ginter et al., 1996). From the results and discussions, it could be suggested that the PCR assay is a suitable diagnostics for the detection of toxin genes and typing of $C$. perfringens from the clinical samples. In this study, сра gene was amplified by PCR and was used for correct identification of the $C$. perfringens isolates. The role of the cpa gene in the pathogenesis of acute diarrhoea in pig and piglet is still not clear because $C$. perfringens type A strains possessing cpa gene is also isolated from healthy piglet control. However, $C$. perfringens type A isolates carrying an additional cpb2 gene is restricted to only diarrhoeic pigs and piglets and absent in healthy pigs and piglets. This suggested that $c p b 2$ gene of $C$. perfringens type $A$ is an essential virulence factor and might play a significant role in occurrence of acute diarrhoea in pigs and piglets in Meghalaya, India. Since C. perfringens is spore forming and both alpha and beta2 toxin can cause diseases in animal and human by entering into the food chain, therefore consumption of pig and piglet meat as pork for human has a crucial impact on public health. As the disease is having public health importance, good management practices, awareness regarding the disease is in first priority. Further, molecular analysis of the pathogen and the role of both $c p a$ and $c p b 2$ genes in association with the disease is required to be understood for undertaking the development of control measures, especially for the formulation of cost effecting vaccine.

\section{ACKNOWLEDGEMENTS}

This research is the part of Ph. D work of first author and was carried out in collaboration with Division of Animal Health, ICAR Research Complex for NEH Region, Umiam, Meghalaya, India and Department of Life Scienece, Assam University, Silchar, Assam, India. Authors gratefully acknowledge or wish to thank the Director, ICAR Research Complex for NEH Region, Meghalaya and Vice Chancellor of Assam University, Silchar for providing the facilities to work.

\section{REFERENCES}

Altschul, S. F., Gish, W., Miller, W., Myers, E. W. and Lipman, D. J. (1990). Basic local alignment search tool. Journal of Molecular Biology 215, 403-410.

Birnboim, H. C. and Doly, J. (1979). A rapid alkaline extraction procedure for screening recombinant plasmid DNA. Nucleic Acid Research 7, 1513-1523.

Bueschel, D. M., Jost, B. H., Billington, S. J., Trinh, H. T. and Songer, J. G. (2003). Prevalence of $c p b 2$, encoding beta2 toxin, in $C$. perfringens field isolates: correlation of genotype with phenotype. Veterinary Microbiology 94, 121-129. 
Czanderlova, L., Hlozek, P., Chmelar, D. and Lany, P. (2006). Clostridium perfringens in suckling piglets with diarrhoea and its PCR typing and prevalence in the Czech Republic in 2001-2003. Veterinarni Medicina 51, 461-467.

Czeczulin, J. R., Hanna, P. C. and Mcclane, B. A. (1993). Cloning, nucleotide sequencing, and expression of the $C$. perfringens enterotoxin gene in Escherichia coli. Infection and Immunity 61, 34293439.

Eisgruber, H., Wiedmann, M. and Stolle, A. (1996). Plasmid profiling for strain differentiation and characterization of $C$. perfringens isolates. Zentralbl Veterinarmed $B$ 43, 137-146.

Garmory, H. S., Chanter, N., French, N. P., Bueschel, D., Songer, J. G. and Titball, R. W. (2000). Occurrence of $C$. perfringens $\beta 2$-toxin amongst animals, determined using genotyping and subtyping PCR assays. Epidemiology and Infection 124, 61-67.

Gibert, M., Jolivet, R. C. and Popoff, M. R. (1997). Beta2 toxin, a novel toxin produced by $C$. perfringens. Gene 203, 65-73.

Ginter, A., Williamsons, E. D., Dessy, F., Coppe, P., Bullifent, H., Howells, A. and Titball, R. (1996). Molecular variation between the alpha toxins from the type strain (NCTC 8237) and clinical isolates of Clostridium perfringens associated with disease in man and animals. Microbiology 142, 191-198.

Holt, J. G., Krige, N. R., Sneeth, P. H. A., Staley, J. T. and Williams, S. T. (1994). Bergey's Manual of Determinative Bacteriology, $9^{\text {th }}$ ed. Williams and Wilkins, Baltimore, USA, pp, 749-755.

Hunter, S. E. C., Clarke, I. N., Kelly, D. C. and Titball, R. W. (1992). Cloning and nucleotide sequencing of the $C$. perfringens epsilon-toxin gene and its expression in Escherichia coli. Infection and Immunity 60, 102-110.

Hunter, S. E. C., Brown, J. E., Oyston, P. C., Sakurai, J. and Titball, R. W. (1993). Molecular genetic analysis of beta-toxin of $C$. perfringens reveals sequence homology with alpha-toxin, Gamma-toxin, and leukocidin of Staphylococcus aureus. Infection and Immunity 61, 3958-3965.

Kanakaraj, R., Harris, D. L., Songer, J. G. and Bosworth, B. (1998). Multiplex PCR assay for detection of Clostridium perfringens in feces and intestinal contents of pigs and swine feed. Veterinary Microbiology 63, 29-38.

Klaasen, H. L., Molkenboer, M. J., Bakker, J., Miserez, R., Hani, H., Frey, J., Popoff M. R. and Van Den Bosch, J. F. (1999). Detection of the beta2 toxin gene of $C$. perfringens in diarrhoeic piglets in the Netherlands and Switzerland. FEMS Immunology and Medical Microbiology 24, 325-332.

Perelle, S., Gibert, M., Boquet, P. and Popoff, M. R. (1993). Characterization of C. perfringens iota-toxin genes and expression in Escherichia coli. Infection and Immunity 61, 5147-5156.

Rooney, A. P., Swezey, J. L., Friedman, R., Hecht, D. W. and Maddox, C. W. (2006). A analysis of core housekeeping and virulence genes reveals cryptic lineages of $C$. perfringens that are associated with distinct disease presentations. Genetics 172, 20812092.

Shome, B. R., Songer, J. G., Shakuntala, I., Shome, R., Kumar, A., Chakraborty, S., Mazumder, Y., Rahman, M. M., Das, A., Murugkar, H. V., Rahman, H. and Bujarbaruah, K. M. (2006). Atypical blackleg caused by $C$. perfringens type $A$ in cattle in Manipur, India. Indian Journal of Animal Science 76, 353-357.

Songer, J. G and Meer, R. R. (1996). Genotyping of $C$. perfringens by polymerase chain reaction is a useful adjunct to diagnosis of clostridial enteric disease in animals. Anaerobe 2, 197-203.

Songer, J. G. (1996). Clostridial enteric diseases of domestic animals. Clinical Microbiology Review 9, 216-234.

Squires, C. H., Heefner, D. L., Evans, R. J., Kopp, B. J. and Yarus, M. J. (1984). Shuttle plasmids for Escherichia coli and C. perfringens. Journal of Bacteriology 159, 465-471.

Titball, R. W., Hunter, S. E. C., Martin, K. L., Morris, A. D., Shuttleworth, A. D., Rubdige, T., Anderson, D. W. and Kelly, D. C. (1989). Molecular cloning and nucleotide sequence of the alpha-toxin (phospholipase C) of C. perfringens. Infection and Immunity 57, 367-376.

Waters, M. A. S., Garmory, H. S., Bueschel, D., Popoff, M. R., Songer, J. G., Titball, R. W., Mcclane, B. A. and Sarker, M. R. (2003). Genotyping and phenotyping of beta2-toxigenic Clostridium perfringens fecal isolates associated with gastrointestinal diseases in piglets. Journal of Clinical Microbiology 41, 3584-359. 